\title{
Characterization of Capsicum chinense Cultigens for Resistance to Meloidogyne arenaria, M. hapla, and M. javanica
}

Judy A. Thies, Research Plant Pathologist, and Richard L. Fery, Research Geneticist, U.S. Vegetable Laboratory, Agricultural Research Service, U.S. Department of Agriculture, 2875 Savannah Highway, Charleston, SC 29414

\begin{abstract}
Thies, J. A., and Fery, R. L. 2001. Characterization of Capsicum chinense cultigens for resistance to Meloidogyne arenaria, M. hapla, and M. javanica. Plant Dis. 85:267-270.

Four Capsicum chinense cultigens with known reactions to Meloidogyne incognita were characterized for resistance to $M$. arenaria races 1 and 2, M. hapla, and M. javanica, in greenhouse and growth-chamber tests. The M. incognita-resistant cultigens PA-353, PA-398, and PA-426 exhibited high resistance to $M$. arenaria race 1 ; the $M$. incognita-susceptible PA-350 was susceptible to $M$. arenaria race 1 . $M$. arenaria race 2 and $M$. javanica were not highly pathogenic to any of the $C$. chinense cultigens. PA-353, PA-398, and PA-426, however, supported an average of 98.1 and $94.8 \%$ fewer $(P<0.05) M$. arenaria race 2 and $M$. javanica eggs per gram fresh root, respectively, than PA-350. $M$. hapla was pathogenic to all four $C$. chinense cultigens. PA353, PA-398, and PA-426 will be useful sources of resistance to $M$. arenaria races 1 and $2, M$. javanica, and $M$. incognita, for developing resistant habanero pepper cultivars; however, an alternative source of resistance must be identified for M. hapla.
\end{abstract}

Additional keywords: host resistance, root-knot nematode, Scotch Bonnet, vegetable breeding

Root-knot nematodes [Meloidogyne incognita (Kofoid \& White) Chitwood, $M$. arenaria (Neal) Chitwood, M. javanica (Treub) Chitwood, and M. hapla Chitwood] are major limiting factors to pepper production in the United States $(19,28,29$, 30,31). Although bell peppers (Capsicum annuum L.) account for most of the pepper production in the United States, both Scotch Bonnet and Habanero peppers $(C$. chinense Jacq.) are becoming increasingly popular with consumers. Currently, methyl bromide and other nematicides are used to control root-knot nematodes in both bell and hot pepper in the United States. Nevertheless, the pending ban of methyl bromide in the United States and the potential loss of other nematicides from the market (due to environmental concerns and high costs of pesticide re-registration) have focused significant interest on host resistance as an alternative to fumigant and non-fumigant nematicides for managing root-knot nematodes in peppers.

A limited number of pepper cultivars are resistant to Meloidogyne species and most of these belong to C. annuum. Martin (20) first identified resistance to root-knot nematodes in a pungent accession of $C$.

Corresponding author: J. A. Thies

E-mail: jthies@awod.com

Accepted for publication 7 November 2000.

Publication no. D-2001-0105-01R

This article is in the public domain and not copyrightable. It may be freely reprinted with customary crediting of the source. The American Phytopathological Society, 2001. annuum, which lead to the development and release of Carolina Hot, a cayenne pepper with resistance to root-knot nematodes (unidentified Meloidogyne spp.) (21). Hare $(13,14)$ identified resistance to $M$. incognita, $M$. javanica, and $M$. arenaria (races not specified) in Santanka $\mathrm{xS}$ and 405B Mexico, and later developed the $M$. incognita-resistant pimiento-type cultivar, Mississippi Nemaheart (15). Fery et al. (8) developed and released Carolina Cayenne, selected from a population of Carolina Hot that was segregating for several traits, including resistance to $M$. incognita. Carolina Cayenne is resistant to $M$. incognita races $1,2,3$, and $4, M$. arenaria races 1 and 2 , and $M$. javanica $(23,27,32)$. Charleston Belle and Carolina Wonder, the first two bell peppers with resistance to $M$. incognita, were developed and released by USDA, ARS, Charleston, SC, in 1997 (9). Charleston Belle and Carolina Wonder are also resistant to M. arenaria races 1 and 2 and M. javanica, but not M. hapla (27).

Hendy et al. $(16,17)$ identified resistance to $M$. arenaria, $M$. javanica, and $M$. incognita in the breeding lines PM 217 and PM 687. Di Vito et al. reported that the $C$. annuum P.I. 159237 and P.I. 159256 are moderately resistant to $M$. incognita, $M$. javanica, and $M$. arenaria (3), and breeding lines 85558 (1) and 89422 (Yolo Wonder $\times$ Tabasco $C$. frutescens L.) (2) are resistant to $M$. incognita. The breeding lines 90533 (Quadrato Giallo $\times$ Tabasco), 90701 (Yolo Wonder $\times$ Tabasco), 90710 (Cayenne $\times$ Tabasco), 90010 (Friariello $\times$ Tabasco), and 90180 (Venus $\times$ Tabasco) are all highly resistant to Italian populations of $M$. incognita races 1 and $2, M$. javanica, and $M$. arenaria race 2 , but susceptible to M. hapla (6).

Information about resistance of C. chinense to Meloidogyne spp. is limited. Surrinam-B, a breeding line of $C$. chinense, is resistant to $M$. incognita and $M$. javanica, but susceptible to $M$. arenaria (3). The $C$. chinense line 201 is resistant to $M$. incognita, $M$. javanica, $M$. arenaria, and $M$. hapla, and line $558-17 \mathrm{e}$ is resistant to $M$. incognita and $M$. arenaria, but susceptible to $M$. hapla and $M$. javanica (5). The $C$. chinense line 56-547/7 is resistant to $M$. incognita, $M$. javanica, and $M$. arenaria (4). In 1998, the U.S. Vegetable Laboratory, USDA, ARS, Charleston, released three Scotch Bonnet (C. chinense) cultigens (PA-353, PA-398, and PA-426) with resistance to $M$. incognita $(10,12)$. The reaction of these cultigens to $M$. arenaria, $M$. javanica, and M. hapla, however, is unknown. Such information is critical for making recommendations on crop rotations to manage different species of root-knot nematodes and is also needed by plant breeders for development of root-knot resistant habanero cultivars. Therefore, the objective of these studies was to determine the reaction of PA-353, PA-398, and PA426 to $M$. arenaria races 1 and $2, M$. javanica, and $M$. hapla in greenhouse and growth chamber tests.

\section{MATERIALS AND METHODS}

Nematode inoculum. $M$. arenaria races 1 and 2, M. javanica, and M. hapla, were increased separately on 'Rutgers' tomato (Lycopersicon esculentum Mill.) in the greenhouse. Cultures of $M$. arenaria races 1 and 2 were obtained from S. A. Lewis (Clemson University, Clemson, SC) and cultures of M. javanica and M. hapla were obtained from K. R. Barker (North Carolina State University, Raleigh). Egg inocula of each Meloidogyne spp. isolate were extracted from infected tomato roots using the $0.5 \% \mathrm{NaOCl}$ method (18).

Pepper genotypes. The pepper genotypes used in all experiments were the control C. аnnиum, cvs. Charleston Belle, Carolina Cayenne, and California Wonder, and C. chinense cultigens PA-353, PA-398, PA-426, and PA-350. Charleston Belle is an $M$. incognita-resistant, open-pollinated bell pepper cultivar (9) that is also resistant to $M$. arenaria races 1 and 2 , and $M$. javanica (27). It is homozygous for the $N$ gene that confers resistance to $M$. arenaria races 1 and 2, $M$. incognita, and $M$. 
javanica $(9,27)$. Carolina Cayenne is resistant to $M$. arenaria races 1 and $2, M$. incognita, and $M$. javanica, and its resistance is conferred by the $N$ gene and an additional recessive gene $(7,23,27)$. California Wonder is a bell pepper that is susceptible to $M$. arenaria races 1 and $2, M$. incognita, M. javanica, and $M$. hapla (11,27). PA-353, PA-398, and PA-426 are Scotch Bonnet-type (C. chinense) cultigens that are resistant to $M$. incognita $(10,12)$. Resistance of PA-426 to $M$. incognita is conditioned by a single dominant gene which is allelic to the $N$ gene (11). PA-350 is a habanero-type ( $C$. chinense) cultigen that is susceptible to $M$. incognita $(10,12)$.

Experimental design and data analysis. All seven pepper genotypes were evaluated in eight separate experiments for reactions to $M$. arenaria races 1 and 2, $M$. hapla, and $M$. javanica. The experimental design for all experiments was a randomized complete block with six replicates (except for the second test with $M$. javanica which had four replicates). Each replicate consisted of five plants of each genotype.

Nematode egg data were $\log _{10}(x+1)$ transformed to normalize the data before analysis (22). Data were analyzed using the GLM procedure of SAS for Windows System Version 6.12 (SAS Institute, Cary, NC) and means were separated using Duncan's multiple range test. Differences reported in the text were significant at the $P$ $<0.05$ level.

Greenhouse experiments. Seven experiments were conducted in the greenhouse: one with $M$. hapla and two each with $M$. arenaria race $1, M$. arenaria race 2 , and M. javanica. Seeds of each pepper genotype were germinated in flats containing Metro-Mix 360 (Scotts, Marysville, $\mathrm{OH})$ in the greenhouse. Three to 4 weeks later, seedlings were transplanted into a 4.0 $\times 1.8 \times 0.25 \mathrm{~m}$ greenhouse bench containing a steam-pasteurized medium of two parts sandy loam soil to one part fine washed river sand $(\mathrm{vol} / \mathrm{vol})$. A $10 \times 10-\mathrm{cm}$ rectangular planting pattern was used. At planting, $5 \mathrm{ml}$ tap water containing approximately 3,000 eggs of the appropriate Meloidogyne spp. and race were pipetted around the base of each plant. Day/night greenhouse temperatures were maintained at $26 \pm 3^{\circ} \mathrm{C}$ for all experiments. Eight to 11 weeks later, the root system of each plant was removed from the growing medium, washed, and rated for severity of root galling and egg mass production using a 1 to 5 scale: $1=0 \%$ to $3 \%$ root system galled or covered with egg masses, $2=4 \%$ to $25 \%, 3=26 \%$ to $50 \%, 4=51 \%$ to $80 \%$, and $5=>80 \%$ root system galled or covered with egg masses (29). Root gall and egg mass indices $\geq 3$ were considered susceptible reactions. The fibrous roots were clipped from the tap root, cut into 1 to 2$\mathrm{cm}$ pieces, and root weights recorded. Eggs were extracted from the entire fibrous root sample using $1.0 \% \quad \mathrm{NaOCl}$ (18) and counted using a stereomicroscope. A nematode reproduction factor $(\mathrm{R})$ was calculated where $R=P_{f} / P_{i}$, with $P_{i}=$ the initial inoculum level and $P_{f}=$ the final population level $(25,26)$.

Growth-chamber experiment. One experiment with $M$. hapla was conducted in the growth chamber. Seedlings were germinated and grown in the greenhouse as previously described for the greenhouse experiments. Three weeks after seeding, seedlings were transplanted into individual $19 \times 3.8$-cm-diameter polyethylene Conetainers (158 $\mathrm{cm}^{3}$ volume) (Stueve and Sons, Corvallis, OR) that had been filled with approximately $150 \mathrm{~cm}^{3}$ of the soil mixture previously described for the greenhouse experiments. At transplanting, $5 \mathrm{ml}$ tap water containing approximately 3,000 eggs of $M$. hapla were pipetted around the base of each plant. The plants were placed in a growth chamber maintained at $25^{\circ} \mathrm{C}$ during a $16 \mathrm{~h} / 8 \mathrm{~h}$ (light/ dark) cycle. Visible radiation was 258 $\mu \mathrm{E} \cdot \mathrm{m}^{2} \cdot \mathrm{s}^{-1}$ during the light cycle. Eight weeks after inoculation, the roots were removed from the soil, washed, rated for severity of root galling and egg mass production, and eggs extracted and counted as previously described.

\section{RESULTS AND DISCUSSION}

The Scotch Bonnet-type $C$. chinense cultigens PA-353, PA-398, and PA-426 exhibited resistance to $M$. arenaria race 1 (Table 1). The habanero-type $C$. chinense cultigen PA-350, however, was highly susceptible to $M$. arenaria race 1 (Table 1). PA-353, PA-398, and PA-426 exhibited minimal root galling (gall index $=1.05$, 1.15 , and 1.02 , respectively, average of two tests) in contrast to PA-350, which exhibited severe root galling (gall index $=4.72$, average of two tests) (Table 1). PA-353, PA-398, and PA-426 had 99.3\%, 96.4\%, and $99.3 \%$, respectively, fewer eggs per gram fresh root than PA-350 (average of two tests). The M. incognita-resistant C. annuum controls 'Charleston Belle' and 'Carolina Cayenne' exhibited high resistance to $M$. arenaria race 1 , but the $M$. incognita-susceptible 'California Wonder' was moderately susceptible to $M$. arenaria race 1 . These results were consistent with those of earlier studies where both 'Charleston Belle' and 'Carolina Cayenne' exhibited high resistance to $M$. arenaria race 1 and 'California Wonder' was susceptible (27). Previous reports of resistance to $M$. arenaria in $C$. chinense include Surrinam-B (3), breeding lines 201 and 55817-C (5), and breeding line 56-547/7 (6).

$M$. arenaria race 2 was not highly pathogenic to any of the $C$. chinense cultigens. PA-353, PA-398, and PA-426 exhibited high resistance to $M$. arenaria race 2, and PA-350 exhibited moderately high resistance (Table 1). There was no visible galling on the roots of PA-353, PA-398, or
PA-426 (gall index $=1.00$, average of two tests). However, minimal galling occurred on the roots of PA-350 (gall index $=1.61$, average of two tests). PA-353, PA-398, and PA-426 had 96.6, 98.6, and 99.1\%, respectively, fewer eggs per gram fresh root than PA-350 (average of two tests). The controls, Charleston Belle and Carolina Cayenne, exhibited little or no root galling (gall index $=1.00$ and 1.03 , respectively, average of two tests), but California Wonder exhibited moderate galling (gall index $=2.31$, average of two tests). The controls, Charleston Belle and Carolina Cayenne, had 99.7 and $98.7 \%$ fewer eggs per gram fresh root than California Wonder. These results confirm those of previous reports where root gall severity and reproduction of $M$. arenaria race 2 were significantly greater for California Wonder than for Charleston Belle and Carolina Cayenne (27).

$M$. javanica was not highly pathogenic to any of the $C$. chinense cultigens (Table 1). PA-353, PA-398, PA-426, and PA-350 exhibited little or no galling (gall index = $1.00,1.00,1.00$, and 1.06 , respectively, average of two tests). PA-353, PA-398, and PA-426 had $88.2 \%, 88.2 \%$, and $96.0 \%$ fewer eggs per gram fresh root, respectively, than PA-350 (average of two tests). PA-350, however, had $86.6 \%$ fewer eggs per gram fresh root than California Wonder. Only about $10 \%$ of $M$. javanica isolates parasitize pepper (24). It appears that the $M$. javanica isolate used in the current studies is not highly pathogenic to pepper, even though the reaction of California Wonder would be considered susceptible since it supported 33,795 eggs per gram fresh root in Test I and 12,573 eggs per gram fresh root in Test II. These results confirm those of previous tests in which California Wonder was susceptible to the same isolate of $M$. javanica (27).

$M$. hapla was pathogenic to all four $C$. chinense cultigens (Table 1). Gall indices ranged from 1.88 to 3.68 (average of two tests). The three $M$. incognita-resistant cultigens (PA-353, PA-398, and PA-426) exhibited less galling (gall index $=2.02$, 1.88 , and 2.12 , respectively, average of two tests) than the $M$. incognita-susceptible PA-350 (gall index $=3.68$ ). PA-353, PA398 , and PA-426 had $79.4 \%, 88.1 \%$, and $82.9 \%$, respectively, fewer eggs per gram fresh root than PA-350 (average of two tests). The three $C$. annuum controls were also susceptible to $M$. hapla. The $M$. incognita-resistant Charleston Belle and Carolina Cayenne, however, exhibited less galling (gall index $=2.79$ and 2.71, respectively, average of two tests) than the $M$. incognita-susceptible California Wonder (gall index $=4.07$, average of two tests). Likewise, Charleston Belle and Carolina Cayenne had 67.2 and $55.2 \%$ fewer eggs per gram fresh root, respectively (average of two tests), than California Wonder. These results confirm a previous report that the $N$ gene does not 
confer resistance to $M$. hapla in $C$. annuum (27). The galling response of the $C$. chinense cultigens to $M$. hapla was approximately 1.5 to $2.5 \times$ greater for the growthchamber test than for the greenhouse test. Similarly, numbers of eggs per gram fresh root were approximately 1.5 to $2.3 \times$ greater for plants in the growth-chamber experiment compared to the greenhouse experiment. The constant day/night temperature of $26^{\circ} \mathrm{C}$ in the growth-chamber experiment may have resulted in greater host plant susceptibility and increased rates of nematode development and reproduction than in the fluctuating ambient temperatures in the greenhouse. We also observed increased reproduction of $M$. arenaria race
2 on C. annuum cultivars grown in the growth chamber compared to the greenhouse in previous experiments (27).

It is likely that the gene that confers resistance to $M$. incognita in the $C$. chinense cultigens PA-353, PA-398, and PA-426 also confers resistance to $M$. arenaria races 1 and 2 and to $M$. javanica. These three cultigens will be useful sources of resistance for the development of habanero cultivars resistant to $M$. incognita, $M$. arenaria, and $M$. javanica. They will also be useful for developing vegetable cropping schemes to manage $M$. incognita, $M$. arenaria, and $M$. javanica, especially when more than one of these Meloidogyne spp. occurs in a field.
ACKNOWLEDGMENTS

This work was supported, in part, by the Integrated Pest Management Collaborative Research Support Program, U.S. Agency for International Development, grant LAG-4196-G-00-3053-00. We gratefully acknowledge the technical assistance of Agricultural Research Technicians E. L. Corley, Jr., J. C. Ferreira, and S. W. Miller.

\section{LITERATURE CITED}

1. Di Vito, M. 1986. Population densities of Meloidogyne incognita and growth of susceptible and resistant pepper plants. Nematol. Mediterr. 14:217-221.

2. Di Vito, M., Cianciotta, V., and Zaccheo, G. 1992. Yield of susceptible and resistant pepper in microplots infested with Meloidogyne incognita. Nematropica 22:1-6.

3. Di Vito, M., and Saccardo, F. 1986. Response of inbred lines of Capsicum to root-knot

Table 1. Gall and egg mass indices, numbers of eggs per gram fresh root mass, and reproductive index of Meloidogyne arenaria race 1, M. arenaria race 2, M. javanica, and M. hapla of four Capsicum chinense cultigens and three $C$. annuum control cultivars in greenhouse or growth-chamber tests ${ }^{\mathrm{u}}$

\begin{tabular}{|c|c|c|c|c|c|c|c|c|}
\hline \multirow[b]{2}{*}{ Tests } & \multicolumn{4}{|c|}{ Test I } & \multicolumn{4}{|c|}{ Test II } \\
\hline & Gall index ${ }^{v}$ & $\begin{array}{c}\text { Egg mass } \\
\text { index }^{v}\end{array}$ & $\begin{array}{c}\text { No. eggs/g } \\
\text { fresh root mass }\end{array}$ & $\begin{array}{c}\text { Reproductive } \\
\text { index }^{\mathrm{w}}\end{array}$ & Gall index $^{v}$ & $\begin{array}{c}\text { Egg mass } \\
\text { index }^{v}\end{array}$ & $\begin{array}{c}\text { No. eggs/g } \\
\text { fresh root mass }\end{array}$ & $\begin{array}{c}\text { Reproductive } \\
\text { index }^{\mathrm{w}}\end{array}$ \\
\hline \multicolumn{9}{|l|}{ M. arenaria race 1} \\
\hline \multicolumn{9}{|l|}{ C. chinense cultigens } \\
\hline PA-353 & $1.03 \mathrm{a}^{\mathrm{x}}$ & $1.05 \mathrm{a}$ & $1,130 \mathrm{~b}^{\mathrm{y}}$ & $0.54 \mathrm{a}^{\mathrm{y}}$ & $1.06 \mathrm{a}$ & $1.06 \mathrm{a}$ & $426 \mathrm{a}^{\mathrm{y}}$ & $0.25 \mathrm{a}^{\mathrm{y}}$ \\
\hline PA-398 & $1.24 \mathrm{a}$ & $1.24 \mathrm{a}$ & $3,517 \mathrm{bc}$ & $2.03 \mathrm{ab}$ & $1.07 \mathrm{a}$ & $1.08 \mathrm{a}$ & $834 \mathrm{a}$ & $0.56 \mathrm{a}$ \\
\hline PA- 426 & $1.03 \mathrm{a}$ & $1.04 \mathrm{a}$ & $1,071 \mathrm{~b}$ & $0.31 \mathrm{~b}$ & $1.01 \mathrm{a}$ & $1.01 \mathrm{a}$ & $783 \mathrm{ab}$ & $0.39 \mathrm{a}$ \\
\hline PA-350 & $4.70 \mathrm{c}$ & $4.67 \mathrm{c}$ & $96,999 \mathrm{~d}$ & $18.62 \mathrm{~d}$ & $4.74 \mathrm{c}$ & $4.69 \mathrm{c}$ & $224,989 \mathrm{c}$ & $46.07 \mathrm{~b}$ \\
\hline \multicolumn{9}{|l|}{ Controls } \\
\hline Charleston Belle $(\mathrm{R})^{\mathrm{z}}$ & $1.00 \mathrm{a}$ & $1.00 \mathrm{a}$ & $253 \mathrm{a}$ & $0.18 \mathrm{a}$ & $1.00 \mathrm{a}$ & $1.00 \mathrm{a}$ & $1,771 \mathrm{a}$ & $1.68 \mathrm{a}$ \\
\hline Carolina Cayenne $(\mathrm{R})^{\mathrm{z}}$ & $1.19 \mathrm{a}$ & $1.20 \mathrm{a}$ & $2,864 \mathrm{bc}$ & $1.60 \mathrm{bc}$ & $1.12 \mathrm{a}$ & $1.12 \mathrm{a}$ & $1,006 \mathrm{a}$ & $0.74 \mathrm{a}$ \\
\hline California Wonder $(\mathrm{S})^{\mathrm{Z}}$ & $2.88 \mathrm{~b}$ & $2.73 \mathrm{~b}$ & $15,617 \mathrm{c}$ & $8.00 \mathrm{c}$ & $2.76 \mathrm{~b}$ & $2.65 \mathrm{~b}$ & $16,832 \mathrm{bc}$ & $10.15 \mathrm{~b}$ \\
\hline \multicolumn{9}{|l|}{ M. arenaria race 2} \\
\hline \multicolumn{9}{|l|}{ C. chinense cultigens } \\
\hline PA-353 & $1.00 \mathrm{a}^{\mathrm{x}}$ & $1.02 \mathrm{a}$ & 249 a & $0.15 \mathrm{a}$ & $1.00 \mathrm{a}$ & $1.00 \mathrm{a}$ & $60 \mathrm{~b}$ & $0.01 \mathrm{~b}$ \\
\hline PA-398 & $1.00 \mathrm{a}$ & $1.00 \mathrm{a}$ & $128 \mathrm{a}$ & $0.08 \mathrm{a}$ & $1.00 \mathrm{a}$ & $1.00 \mathrm{a}$ & $0 \mathrm{a}$ & $0.00 \mathrm{a}$ \\
\hline PA- 426 & $1.00 \mathrm{a}$ & $1.00 \mathrm{a}$ & $79 \mathrm{a}$ & $0.07 \mathrm{a}$ & $1.00 \mathrm{a}$ & $1.00 \mathrm{a}$ & $5 \mathrm{a}$ & $0.00 \mathrm{a}$ \\
\hline PA-350 & $1.58 \mathrm{~b}$ & $1.41 \mathrm{~b}$ & $7,547 \mathrm{~b}$ & $2.54 \mathrm{~b}$ & $2.15 \mathrm{~b}$ & $1.64 \mathrm{~b}$ & $1,617 \mathrm{c}$ & $0.06 \mathrm{c}$ \\
\hline \multicolumn{9}{|l|}{ Controls } \\
\hline Charleston Belle $(\mathrm{R})^{\mathrm{z}}$ & $1.00 \mathrm{a}$ & $1.00 \mathrm{a}$ & $62 \mathrm{a}$ & $0.03 \mathrm{a}$ & $1.00 \mathrm{a}$ & $1.00 \mathrm{a}$ & $4 \mathrm{a}$ & $0.00 \mathrm{a}$ \\
\hline Carolina Cayenne $(\mathrm{R})^{\mathrm{z}}$ & $1.05 \mathrm{a}$ & $1.05 \mathrm{a}$ & $323 \mathrm{a}$ & $0.27 \mathrm{a}$ & $1.00 \mathrm{a}$ & $1.00 \mathrm{a}$ & $4 \mathrm{a}$ & $0.00 \mathrm{a}$ \\
\hline California Wonder $(S)^{\mathrm{z}}$ & $1.81 \mathrm{~b}$ & $1.75 \mathrm{c}$ & $19,924 \mathrm{~b}$ & $7.75 \mathrm{~b}$ & $2.80 \mathrm{c}$ & $2.72 \mathrm{c}$ & $5,907 \mathrm{~d}$ & $0.68 \mathrm{~d}$ \\
\hline \multicolumn{9}{|l|}{ M. javanica } \\
\hline \multicolumn{9}{|l|}{ C. chinense cultigens } \\
\hline PA-353 & $1.00 \mathrm{a}^{\mathrm{x}}$ & $1.00 \mathrm{a}$ & $90 \mathrm{a}$ & $0.01 \mathrm{a}$ & $1.00 \mathrm{a}$ & $1.00 \mathrm{a}$ & $175 \mathrm{ab}$ & $0.01 \mathrm{a}$ \\
\hline PA-398 & $1.00 \mathrm{a}$ & $1.00 \mathrm{a}$ & $182 \mathrm{a}$ & $0.04 \mathrm{a}$ & $1.00 \mathrm{a}$ & $1.00 \mathrm{a}$ & $11 \mathrm{ab}$ & $0.00 \mathrm{a}$ \\
\hline PA-426 & $1.00 \mathrm{a}$ & $1.00 \mathrm{a}$ & $43 \mathrm{a}$ & $0.01 \mathrm{a}$ & $1.00 \mathrm{a}$ & $1.00 \mathrm{a}$ & $38 \mathrm{~b}$ & $0.00 \mathrm{a}$ \\
\hline PA-350 & $1.12 \mathrm{a}$ & $1.01 \mathrm{a}$ & 798 a & $0.04 \mathrm{a}$ & $1.00 \mathrm{a}$ & $1.00 \mathrm{a}$ & $1,438 \mathrm{c}$ & $0.14 \mathrm{~b}$ \\
\hline \multicolumn{9}{|l|}{ Controls } \\
\hline Charleston Belle $(\mathrm{R})^{\mathrm{z}}$ & $1.07 \mathrm{a}$ & $1.07 \mathrm{a}$ & $752 \mathrm{a}$ & $0.10 \mathrm{a}$ & $1.00 \mathrm{a}$ & $1.00 \mathrm{a}$ & $0 \mathrm{a}$ & $0.01 \mathrm{a}$ \\
\hline Carolina Cayenne $(\mathrm{R})^{\mathrm{z}}$ & $1.00 \mathrm{a}$ & $1.00 \mathrm{a}$ & $79 \mathrm{a}$ & $0.02 \mathrm{a}$ & $1.00 \mathrm{a}$ & $1.00 \mathrm{a}$ & $13 \mathrm{ab}$ & $0.00 \mathrm{a}$ \\
\hline California Wonder $(S)^{\mathrm{z}}$ & $2.16 \mathrm{~b}$ & $2.09 \mathrm{~b}$ & $33,795 \mathrm{~b}$ & $5.95 \mathrm{~b}$ & $1.38 \mathrm{~b}$ & $1.42 \mathrm{~b}$ & $12,573 \mathrm{c}$ & $2.13 \mathrm{c}$ \\
\hline \multicolumn{9}{|l|}{ M. hapla } \\
\hline \multicolumn{9}{|l|}{ C. chinense cultigens } \\
\hline PA-353 & $2.87 \mathrm{ab}^{\mathrm{x}}$ & $2.77 \mathrm{~b}$ & $20,809 \mathrm{~b}$ & $6.42 \mathrm{~b}$ & $1.16 \mathrm{a}$ & $1.20 \mathrm{a}$ & $14,199 \mathrm{a}$ & $1.29 \mathrm{a}$ \\
\hline PA-398 & $2.67 \mathrm{a}$ & $2.59 \mathrm{a}$ & $12,612 \mathrm{a}$ & $5.31 \mathrm{a}$ & $1.09 \mathrm{a}$ & $1.07 \mathrm{a}$ & $7,704 \mathrm{a}$ & $0.61 \mathrm{a}$ \\
\hline PA- 426 & $3.07 \mathrm{~b}$ & $3.05 \mathrm{~b}$ & $19,885 \mathrm{~b}$ & $8.32 \mathrm{~b}$ & $1.16 \mathrm{a}$ & $1.16 \mathrm{a}$ & $9,165 \mathrm{ab}$ & $1.42 \mathrm{~b}$ \\
\hline PA-350 & $4.45 \mathrm{~d}$ & $4.60 \mathrm{~d}$ & $118,422 \mathrm{e}$ & $31.99 \mathrm{~d}$ & $2.90 \mathrm{c}$ & $2.77 \mathrm{c}$ & $51,839 \mathrm{c}$ & $5.23 \mathrm{c}$ \\
\hline \multicolumn{9}{|l|}{ Controls } \\
\hline Charleston Belle $(\mathrm{R})^{\mathrm{z}}$ & $3.36 \mathrm{c}$ & $3.55 \mathrm{c}$ & $23,622 \mathrm{bc}$ & $13.26 \mathrm{c}$ & $2.21 \mathrm{~b}$ & $2.05 \mathrm{~b}$ & $29,210 \mathrm{c}$ & $6.32 \mathrm{c}$ \\
\hline Carolina Cayenne $(\mathrm{R})^{\mathrm{z}}$ & $3.38 \mathrm{c}$ & $3.40 \mathrm{c}$ & $29,907 \mathrm{c}$ & $12.25 \mathrm{c}$ & $2.03 \mathrm{~b}$ & $1.82 \mathrm{~b}$ & $42,316 \mathrm{c}$ & $4.61 \mathrm{c}$ \\
\hline California Wonder $(S)^{z}$ & $4.95 \mathrm{e}$ & $4.96 \mathrm{e}$ & $67,888 \mathrm{~d}$ & $30.76 \mathrm{~d}$ & $3.18 \mathrm{c}$ & $2.99 \mathrm{c}$ & $93,395 \mathrm{~d}$ & $11.5 \mathrm{c}$ \\
\hline
\end{tabular}

${ }^{\mathrm{u}}$ Two tests were conducted for each Meloidogyne sp./race combination. Both tests for $M$. arenaria race 1 and $M$. javanica were conducted in the greenhouse. The first $M$. hapla test was conducted in the growth chamber and the second $M$. hapla test was conducted in the greenhouse. Each plant was inoculated with approximately 3,000 eggs of $M$. arenaria race $1, M$. arenaria race 2, M. javanica, or $M$. hapla at transplanting. Data are means of six replicates $(n=30)$.

${ }^{v}$ Rated on a scale of 1 to $5: 1=0$ to $3 \%$ root system galled or covered with egg masses, $2=4$ to $25 \%, 3=26$ to $50 \%, 4=51$ to $80 \%$, and $5=>80 \%$.

${ }^{\mathrm{w}}$ Reproductive index $=\mathrm{Pf}$ (final population)/Pi (initial inoculum).

${ }^{x}$ Values in a column within tests followed by the same letter are not different $(P<0.05)$ according to Duncan's multiple range test.

y Data were $\log _{10}(x+1)$ transformed before analysis. Untransformed data are shown.

${ }^{\mathrm{z}} \mathrm{R}=$ resistant; $\mathrm{S}=$ susceptible. 
nematode (Meloidogyne spp.). Pages 119-123 in Proc. Sixth EUCARPIA Meeting on Genetics and Breeding on Capsicum and Eggplant, Zaragoza, Spain, 21-24 Oct. 1986.

4. Di Vito, M., Saccardo,F., Errico, A., Zema, V., and Zaccheo, G. 1993. Genetics of resistance to root-knot nematodes (Meloidogyne spp.) in Capsicum chacoense, $C$. chinense, and $C$. frutescens. J. Genet. Breed. 47:23-26.

5. Di Vito, M., Saccardo, F., and Sasanelli, N. 1989. Reaction of lines of Capsicum spp. to root-knot nematodes (Meloidogyne spp.). Pages 171-175 in N. Marinkovic, Z. Miladinovic, D. Stevanovic, Dj. Gvozdenovic, D. Jankulovski, eds. EUCARPIA Seventh meeting on genetics and breeding on Capsicum and eggplant, Kragujevac, Yugoslavia, 27-30 June 1989.

6. Di Vito, M., Saccardo, F., and Zaccheo, G. 1993. Response of new lines of pepper to Meloidogyne incognita, $M$. javanica, $M$. arenaria and M. hapla. Afro-Asian J. Nematol. $3: 135-138$.

7. Fery, R. L., and Dukes, P. D. 1996. The inheritance of resistance to the southern rootknot nematode in 'Carolina Hot' cayenne pepper. J. Amer. Soc. Hort. Sci. 121:10241027.

8. Fery, R. L., Dukes, P. D., and Ogle, W. L. 1986. 'Carolina Cayenne' pepper. HortScience 21:330.

9. Fery, R. L., Dukes, P. D., Sr., and Thies, J. A. 1998. 'Carolina Wonder' and 'Charleston Belle': Southern root-knot nematode resistant bell peppers. HortScience 33:900-902.

10. Fery, R. L., and Thies, J. A. 1997. Evaluation of Capsicum chinense Jacq. cultigens for resistance to the southern root-knot nematode. HortScience 32:923-926.

11. Fery, R. L., and Thies, J. A. 1998. Genetic analysis of resistance to the southern rootknot nematode in Capsicum chinense Jacq. J. Amer. Soc. Hort. Sci. 123:1008-1011.

12. Fery, R. L., and Thies, J. A. 1998. PA-353, PA-398, and PA-426: southern root-knot nematode resistant Capsicum chinense Jacq. germplasm lines. HortScience 33:760-761.

13. Hare, W. W. 1956. Comparative resistance of seven pepper varieties to five root-knot nematodes. Phytopathology 46:669-672.

14. Hare, W. W. 1957. Inheritance of resistance to root-knot nematodes in pepper. Phytopathology 47:455-459.

15. Hare, W. W. 1966. New pimiento is resistant to nematodes. Miss. Farm Res. 29:1,8.

16. Hendy, H., Dalmasso, A., and Cardin, M. C. 1985. Differences in resistant Capsicum annuum attacked by different Meloidogyne species. Nematologica 31:72-78.

17. Hendy, H., Pochard, E., and Dalmasso, A. 1985. Transmission héréditaire de la résistance aux nématodes Meloidogyne Chitwood (Tylenchida) portee par 2 lignées de Capsicum annuum L.: Etude de descendances homozygotes issues d'androgenèse. Agronomie 5:93100

18. Hussey, R. S. and Barker, K. R. 1973. A comparison of methods of collecting inocula of Meloidogyne spp., including a new technique. Plant Dis. Rep. 57:1025-1028.

19. Lindsey, D. L., and Clayshulte, M. S. 1982. Influence of initial population densities of Meloidogyne incognita on three chile cultivars. J. Nematol. 14:353-358.

20. Martin, J. A. 1948. Breeding of pungent peppers. S. C. Agric. Exp. Sta. Ann. Rep. 60:64-67.

21. Martin, J. A., and Crawford, J. H. 1958. Carolina Hot pepper. S. C. Agric. Exp. Sta. Cir. 117.

22. Noe, J. P. 1985. Analysis and interpretation of data from nematological experiments. Pages 187-196 in K. R. Barker, C. C. Carter, and J. N. Sasser, eds. An advanced treatise on Meloidogyne Volume II: Methodology. North Carolina State University Graphics, Raleigh.

23. Noe, J. P. 1992. Variability among populations of Meloidogyne arenaria. J. Nematol. 24:404-414.

24. Sasser, J. N., and Carter, C. C. 1982. Rootknot nematodes (Meloidogyne spp.): Identifi- cation, morphological and physiological variation, host range, ecology, and control. Pages 21-32 in R. D. Riggs, and ed. committee, Southern Regional Research Committees S-76 and S-154, eds. Nematology in the southern region of the United States. South. Coop. Ser. Bull. 276. October 1982.

25. Sasser, J. N., Carter, C. C., and Hartman, K. M. 1984. Standardization of host suitability studies and reporting of resistance to rootknot nematodes. Crop Nematode Res. Control Proj. NC State Univ., U.S. Agency for Intl. Dev., Raleigh.

26. Taylor, A. L., and Sasser, J. N. 1978. Biology, identification and control of root-knot nematodes (Meloidogyne spp.). NC State Univ. Dep. Plant Path., and USAID, Raleigh.

27. Thies, J. A., and Fery, R. L. 2000. Characterization of resistance conferred by the $N$ gene to Meloidogyne arenaria races 1 and $2, M$. hapla, and $M$. javanica in two sets of isogenic lines of Capsicum annuum L. J. Amer. Soc Hort. Sci. 125:71-75.

28. Thies, J. A., Mueller, J. D., and Fery, R. L. 1997. Effectiveness of resistance to southern root-knot nematode in 'Carolina Cayenne' pepper in greenhouse, microplot, and field tests. J. Amer. Soc. Hort. Sci. 122:200-204.

29. Thies, J. A., Mueller, J. D., and Fery, R. L. 1998. Use of a resistant pepper as a rotational crop to manage southern root-knot nematode. HortScience 33:716-718.

30. Thomas, S. H. 1994. Influence of 1,3dichloropropene, fenamiphos, and carbofuran on Meloidogyne incognita populations and yield of chile peppers. Suppl. to J. Nematol. 26:683-689.

31. Thomas, S. H., Murray, L. W., and Cardenas, M. 1995. Relationship of preplant population densities of Meloidogyne incognita to damage in three chile pepper cultivars. Plant Dis. 79:557-559.

32. Zamora, E., Bosland, P. W., and Thomas, S. 1994. Carolina Cayenne as a source of resistance to Meloidogyne incognita races 1, 2, 3, and 4. HortScience 29:1184-1185. 